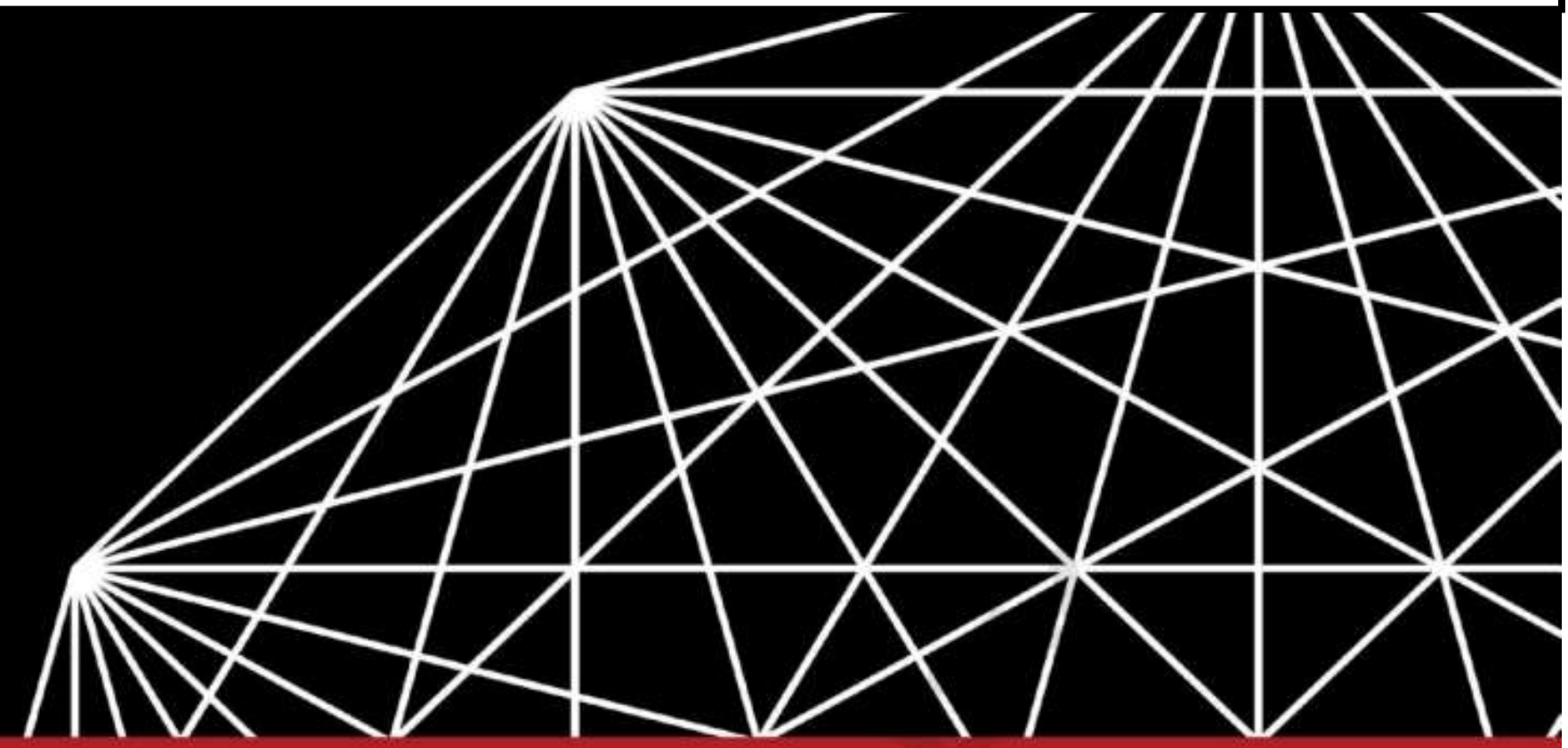

\title{
ENGLISH LINGUISTICS, LITERATURE, AND LANGUAGE TEACHING IN A CHANGING ERA
}

Edited by

Suwarsih Madya, Willy A. Renandya, Masaki Oda, Didi Sukiyadi, Anita Triastuti, Ashadi, Erna Andriyanti and Nur Hidayanto P.S.P

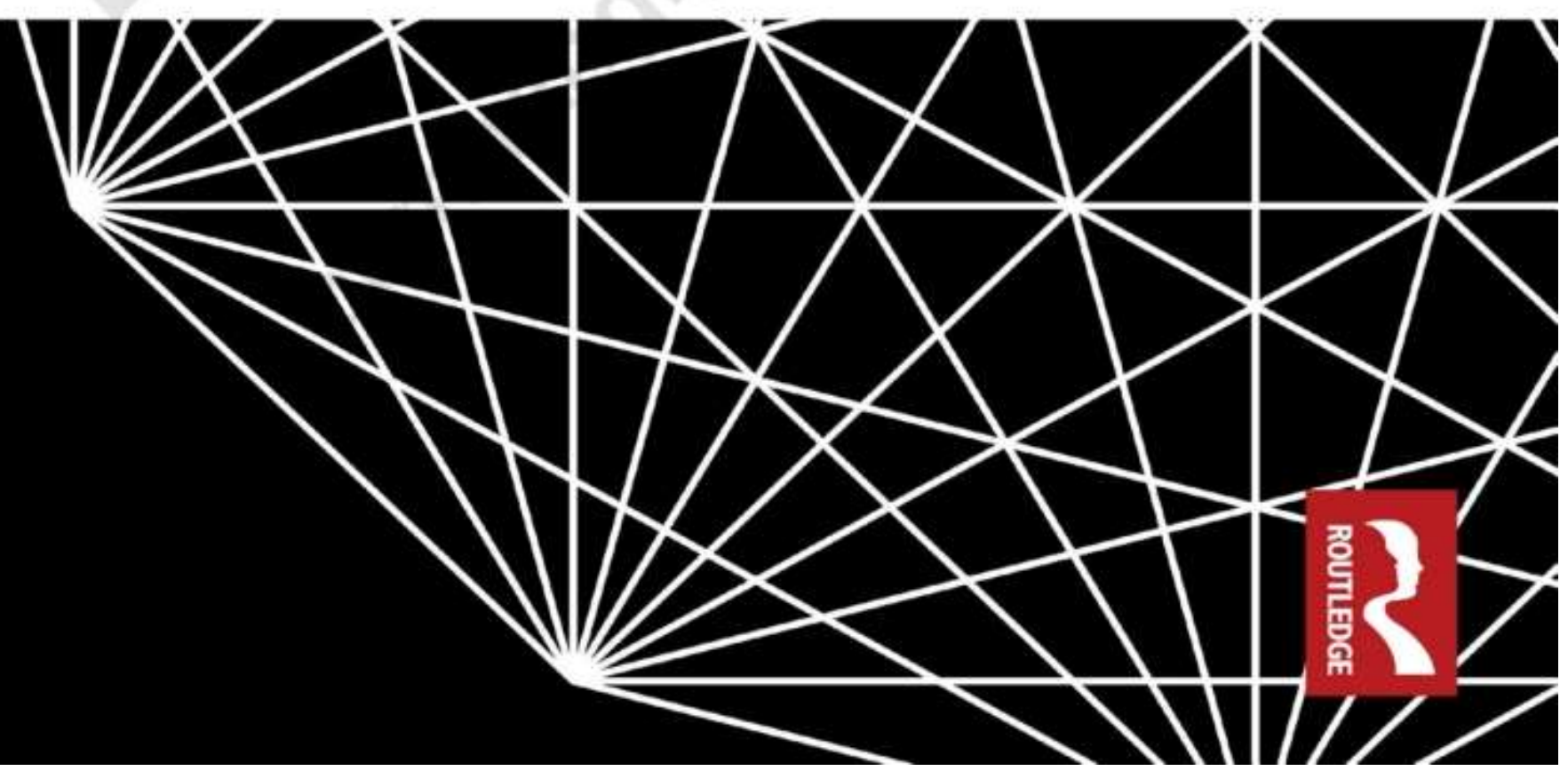




\section{English Linguistics, Literature, and Language Teaching in a Changing Era}

\section{Edited by}

Suwarsih Madya

Universitas Negeri Yogyakarta, Indonesia

Willy A. Renandya

Nanyang Technological University, Singapore

Masaki Oda

Tamagawa University, Japan

Didi Sukiyadi

Universitas Pendidikan Indonesia, Indonesia

Anita Triastuti

Universitas Negeri Yogyakarta, Indonesia

Ashadi

Universitas Negeri Yogyakarta, Indonesia

Erna Andriyanti

Universitas Negeri Yogyakarta, Indonesia

Nur Hidayanto P.S.P

Universitas Negeri Yogyakarta, Indonesia 
All rights reserved. No part of this publication or the information contained herein may be reproduced, stored in a retrieval system, or transmitted in any form or by any means, electronic, mechanical, by photocopying, recording or otherwise, without written prior permission from the publisher.

Although all care is taken to ensure integrity and the quality of this publication and the information herein, no responsibility is assumed by the publishers nor the author for any damage to the property or persons as a result of operation or use of this publication and/or the information contained herein.

Published by: CRC Press/Balkema

Schipholweg 107C, 2316XC Leiden, The Netherlands

e-mail: Pub.NL@taylorandfrancis.com

www.crcpress.com - www.taylorandfrancis.com

ISBN: 978-0-367-07501-9 (Hbk)

ISBN: 978-0-429-02103-9 (eBook)

DOI: https://doi.org/10.1201/9780429021039 


\section{Table of contents}

Preface

Acknowledgement

$\mathrm{xi}$

Organizing Committee

\section{Plenary Presentation Papers}

Exploring language teacher identity through short story analysis in a disruptive era

Gary Barkhuizen

Literature and literacy in the changing era: Will disruptive bring an end to literature?

Manneke Budiman

Groundless beliefs: Language learners and media discourse

Masaki Oda

Going beyond communicative competence to become literate national and global citizens

Suwarsih Madya

\section{Part I: English Linguistics}

Materializing colonial heritage in Goa Belanda

Agung Farid \& R. Vindy M. Puspa

English and Javanese greeting expressions: A descriptive qualitative study on pragmatics Ayu T. Andayani \& Basikin

\section{Part II: Literature}

Ryunosuke Akugatawa's Kappa: Warning against the dangers and pitfalls of modernization Orestis Soidi, Emzir \& J. H. Tamboto

Disruptive creativity as represented by Jane Austen \& Seth Grahame-Smith's Pride and Prejudice and Zombies

Ratna Asmarani

Cultural term translation in Der Prozess Novel by Frans Kafka: Analysis of translation methods and ideology

Sulfah Risna \& Pratomo Widodo

Digital literacy practices of English language learners: Indonesian context

Westi. H. Utami, Didi Suherdi \& Pupung Purnawarman

\section{Part III: English Language Teaching in Changing Era}

Teaching critical thinking through reading to Senior High School students 
Effects of Think Pair Share strategy on Indonesian vocational higher institution students' speaking skills

Alfi H. Miqawati \& Fitri Wijayanti

Predict, Locate, Add, and Note (PLAN) strategy: An effective way to assist EFL students' reading comprehension in task-based learning

Annisa Rizqiana \& Anita Triastuti

Professional development challenges for Indonesian English teachers

Astri O. Kuncahya \& Basikin

Automatic speech recognition to enhance EFL students' pronunciation through Google's Voice Search application

Cherlie E. Rayshata \& Dyah S. Ciptaningrum

Factors influencing anxiety of non-native ESL teachers in compulsory schooling

Cindyra Galuhwardani \& Bambang W. Pratolo

A descriptive case study on accommodating Turnitin to optimize the role of portfolio assessment and self-assessment for students' writing process

Dewi Cahyaningrum, Hasan Zainnuri \& Ngadiso

Foreign language anxiety in relation with students' motivation: What's the matter?

Dyta Maykasari \& Widyastuti Purbani

The influence of Computer Assisted Language Learning (CALL) to improve English speaking skills

Dyah Ratnaningsih, Damoyanto Purba, Daviq Wiratno \& Faris Nofandi

Enhancing Indonesian elementary students' engagement in learning English through cooperative learning strategies

Emeral, Dyah S. Ciptaningrum, Elsa M. Marahati \& Thuthut Kartikarini

The implementation of intercultural language learning in teaching Indonesian as a foreign language to international students

Godlove Kiswaga \& Anita Triastuti

The implementation of MOOC using Schoology towards students' learning outcomes

Hasan Zainmuri, Ngadiso \& Dewi Cahyaningrum

The effect of online extensive reading in building the reading fluency of EFL university

students

Hendriwanto \& Utut Kurniati

English Teachers' perception on the implementation of character education in Curriculum 2013

Heni P. Lestari \& Bambang W. Pratolo

Raising English students' intercultural awareness through cultural texts

Indah Permatasari \& Erna Andriyanti

Tertiary students' anxiety in speaking English

Muamaroh, Nur Hidayat \& Sri Lestari

Developing integrated English learning materials of Islamic contents based on instructional analysis: A design-based research

Muhammad Saifuddin \& Dwi Nurcahyani

An investigation into the English language writing strategies used by Indonesian EFL

graduate students

Nanik Rahmawati, Endang Fauziati \& Sri Marmanto 
Let's speak: Encouraging students to speak up in the classroom through project-based learning

Nur I. Muslim, Yulia N. Hidayah, Iffah Mayasari \& Ashadi

Investigating self-correction strategies for oral grammatical errors and their merit in language acquisition among EFL learners

Nurul Marlisa \& Ashadi

Proposing literature circle strategy to enhance students' reading comprehension in EFL

classroom

Nurus Sa'adah \& Erna Andriyanti

The representation of cultural elements in the promotion of intercultural communicative competence in senior high school EFL textbooks in Indonesia

Oktavia Herawati

The significance of teacher's talent in improving students' engagement in EFL classroom Puspita Wijayati \& Erna Andriyanti

English language learning needs of culinary students in vocational school

Richa A. Shara \& Erna Andriyanti

Narrative story cards for ELT: A report on their development and effectiveness

Richard J. Stockton

EFL adult learners' perceptions on language anxiety toward the speaking performance

Rini Ardiani \& Bambang W. Pratolo

The differentiated types of role play to enhance speaking in contextual learning

Sarah M. Azizah \& Dyah S. Ciptaningrum

Looking at learner engagement in a digital multimodal-based instruction

Siti Kustini

Developing the model of teaching materials for ESP (English for Specific Purposes)

Stefhani R. Rahmawati, Emzir \& Aceng

The integration of character education in reading classes at the English Education

Department

Sugirin, Siti Sudartini \& Ani Setyaningsih

The implementation of Moodle platform to help teachers develop blended learning in the field of Teaching English as a Foreign Language (TEFL)

Tchello Kasse \& Anita Triastuti

Administering a need analysis survey to young EFL learners in Yogyakarta

Thuthut Kartikarini, Dyah S. Ciptaningrum, Emeral, Elsa M. Marahati \& Septiana W.

Setyaningrum

Improving speaking skills through role plays for nursing students in Indonesian context

Tri W. Floriasti \& Indah Permatasari

Developing the students' reflective skills in teaching and learning of reading in disruptive era

Umi Rachmawati

Out-of-class language learning activities: A case study of good language learners

Wawan Cahyadin \& Halijah Koso

Investigating individual's clarity of enunciation with Orai application: implications for L2 assessment

Widya R. Kusumaningrum \& Rangga Asmara 
A need analysis of hearing-impaired students writing materials

Wikandari M. Puspasari \& Ashadi

$\mathrm{L} 1$ and L2 Classroom: Does it truly assist learning?

Zefki O. Feri \& Ashadi

Author Index 


\title{
EFL adult learners' perceptions of language anxiety toward speaking performance
}

\author{
Rini Ardiani \& Bambang W. Pratolo \\ English Education, Universitas Ahmad Dahlan, Yogyakarta, Indonesia
}

\begin{abstract}
A considerable number of foreign as well as second language learners suffer from language anxiety when they step into the language classroom. This research drew on a small study which was carried out at a private university in Yogyakarta to understand the factors that affect English as a Foreign Language (EFL) adult learners' language anxiety toward speaking performances. The purpose of this study is to report findings from the qualitative interview data on the factors of EFL adult learners' language anxiety toward speaking performance. The participants were six postgraduate students who were chosen randomly. The data were collected through semi-structured interviews guided by an interview protocol. The demographic data were analyzed descriptively while the interview data were transcribed and analyzed line by line to generate and develop codes and themes. An analysis of the interview data revealed five major themes, including (1) linguistic difficulties, (2) cognitive challenges, and (3) lack of practice in speaking English. Some ways to deal with language anxiety are also explained and suggestions for future study are provided.
\end{abstract}

Keywords: Perceptions, language anxiety, speaking performance

\section{INTRODUCTION}

English as a Foreign Language (EFL) has been challenging for Indonesian students. The positive thing is that learners are motivated to learn English because it is the official language of many international and professional organizations. But, unfortunately, it is not easy for Indonesian students to learn English because they have some challenges in learning it, including anxiety. Horwitz, Horwitz and Cope [1] defined anxiety as 'the subjective feeling of tension, apprehension, nervousness, and worry associated with an arousal of the autonomic nervous system' (p. 125). They discussed foreign language anxiety as 'a distinct complex of selfperception, beliefs, feelings, and behaviors related to classroom language learning arising from the uniqueness of the language learning process' (p. 128). This means that language anxiety is an awkward feeling and psychological pressure that learners experience when learning a language or accomplishing a task [2]. Even students at a higher level of education may have anxiety around foreign language learning.

Factors that could contribute to speaking anxiety are linguistic difficulties, cognitive challenges, a lack of information in the first language, competitiveness, and the role of teachers. The study conducted by Kayaoğlu and Sağlamel [3] among Turkish students stated that students' language anxiety is caused by linguistic difficulties including: vocabulary, pronunciation, grammar and sentence structure; cognitive challenges including fear of failure (failing to communicate, failing in exams, making mistakes, and failing in front of others); lack of information in the first language; competitiveness; the teacher's role, which leads students to have a high level of anxiety and low confidence in their language performance. Motivation can be another reason for being anxious. Tanveer's study showed that anxiety can be caused by intrinsic motivation. Accordingly, students' beliefs, opinions and lack of language instruction 
can lead to a higher level of anxiety. Other factors such as the social and cultural environments can also be reasons for anxiety-provoking situations [3]. Students' anxiety might also be related to gender: a survey of previous studies showed that gender influences the level of foreign language anxiety among learners $[4,5,6,7,8,9]$.

With regard to the effects of anxiety, students might face some challenges or difficulties in expressing themselves in the language with effects that may be academic, cognitive, social or personal [9]. These kinds of effects may produce negative feelings in learners when they come to communicate in the target language and can affect their performance, especially when speaking. In one study, Aydin [10] stated that there are some negative correlations between achievement and anxiety. Firstly, EFL students may suffer from language anxiety provoked by factors including: not being prepared for classroom activity; being apprehensive about communicating with teachers, peers, and native speakers; teachers' questions and corrections in the classroom environment; assessments and negative attitudes towards English courses. Secondly, language anxiety is caused by the feeling of being afraid of being evaluated by others. This consists of fear of negative judgments by others, of making an unfavorable impression on others, of making verbal or spelling mistakes, and of displeasing others. Being afraid of negative evaluation is a general factor of foreign language anxiety. This negative evaluation leads to the fear of being called on in class; assessment anxiety; communication apprehension with peers, native speakers, and teachers; fear of making mistakes while speaking; negative attitudes towards language learning, and feeling anxious when teachers ask questions and make corrections of their performance.

Language anxiety can affect students' speaking performance in many ways. A study conducted by Kayaoğlu and Sağlamel [3] among Turkish students stated that students are visibly different when they are anxious. They believe that some differences occur when they feel anxious, and these effects can be physical, psychological, cognitive, linguistic, and behavioral.

A number of previous studies have investigated language anxiety for EFL students at university level $[3,10,11,12,13,14,15,16]$. This study is an attempt to explore how language anxiety affects EFL adult learners' speaking performance. It aims to answer the research question on the perceptions of EFL adult learners about language anxiety regarding speaking performance. This research question then leads to two supplementary questions: How does language anxiety affect EFL adult learners' speaking performance? How do EFL adult learners deal with language anxiety?

\section{RESEARCH METHOD}

Our investigation used a qualitative approach because it involved a small-scale study and looked at EFL adult learners' perceptions and interpretations of the factors in language anxiety regarding speaking performance. This was useful and practical because it allowed the researcher to conduct an in-depth analysis of the data [15]. The study was conducted at an Indonesian private university in Yogyakarta with six EFL students who were in the first year of a postgraduate program in English education. A purposeful sampling with a convenient case strategy was used, following what Creswell [17] described as the concept of purposeful sampling used in qualitative research. This means that the inquirer selects individuals and sites for the study because they can purposefully inform an understanding of the research problems...' (p. 125) and 'convenience cases, which represent sites or individuals from which researchers can access and easily collect data' (p. 126).

A semi-structured interview was used to collect the data and was carried out in April 2018. The process of collecting the data involved recruiting the participants first, then conducting the research by doing an interview which lasted between 10 and 15 minutes. The interview was recorded with the researcher's mobile phone. The demographic data were then analyzed descriptively in the form of data transcription of the information given by the participants. The interview data were transcribed and analyzed line by line to identify the categories among the data. In order to guarantee the trustworthiness (Lincoln \& Guba, 1985, cited in [18]) of this study and to verify the accuracy of the data, findings, and interpretations [19], the 
Table 1. Participants' background information.

\begin{tabular}{llllll}
\hline No. & Name & Gender & Age & Major & Current Status \\
\hline 1 & Lisa & Female & 24 & English Education & First-year study \\
2 & Feby & Female & 24 & English Education & First-year study \\
3 & Tania & Female & 25 & English Education & First-year study \\
4 & Akbar & Male & 24 & English Education & First-year study \\
5 & Fendi & Male & 25 & English Education & First-year study \\
6 & Indra & Male & 26 & English Education & First-year study \\
\hline
\end{tabular}

researcher then returned the interview data transcriptions to each participant to ensure that the data remained valid and had not been manipulated.

\section{FINDINGS AND DISCUSSION}

This study was intended to report on some of the factors of English language anxiety regarding speaking performance as experienced by EFL adult learners at a private university in Yogyakarta, Indonesia. The analysis and discussions were organized according to the participants' accounts, feelings, and thoughts regarding the factors of English language anxiety that they experienced. An analysis of the interview data revealed three main categories that related to EFL adult learners' perceptions: (1) linguistic difficulties, (2) cognitive challenges, (3) lack of practice in speaking English.

It cannot be denied that many EFL students experienced difficulties using the English language, especially when speaking. The finding has also shown, in terms of the first supplementary research question, that there are some obstacles faced by EFL adult learners, especially when speaking English in public. At the start of language learning, a learner will face some difficulties with the language learning process, understanding grammar and other language aspects. If that student becomes anxious about this, then they become uncomfortable in making errors, resulting in anxiety. Thus, the first factor, and possibly the most significant aspect for EFL adult learners, is linguistic difficulties due to speaking anxiety. Although the learners are in higher level education, the study shows that they still face difficulties in speaking English, especially anxiety. Of the linguistic difficulties, vocabulary and pronunciation were reported to have the strongest effect on students' speaking performance. Most of the participants stated that it was vocabulary and mispronunciation of words (P1, P2, P3, P4 and P6) that made it challenging for them to speak in front of others because they didn't have enough vocabulary to speak fluently. Grammar (P1, P2, P3 and P4) was also reported as a linguistic difficulty due to language anxiety around speaking performance [3].

From the interviews carried out during the study, linguistic difficulties appeared to be one of the factors in the language anxiety which influenced students' speaking performance. Participants stated that they felt anxious about English due to a variety of problems. Five of the participants admitted that difficulties in pronunciation, lack of vocabulary and grammatical knowledge were the main factors that led them to feel anxious or hesitant in speaking English. Comments they made included:

'In English, I felt difficulty in translating because I do not know the vocabulary and the grammar for speaking; I think it is hard for me' [P1/Lisa]

Table 2. Themes of factors in EFL adult learners' speaking anxiety.

\begin{tabular}{lll}
\hline No. & Theme & Participants $(\mathrm{N}=6)$ \\
\hline 1 & Linguistic difficulties & 5 \\
2 & Cognitive challenges & 5 \\
3 & Lack of practice in speaking English & 3 \\
\hline
\end{tabular}




\begin{abstract}
'Yeah, of course, it is about pronunciation, grammar and also vocabularies' [P2/Feby]
$\because$... First, less of vocabulary, then lack of pronunciation, yeah, I think those are the basis of factors that make me feel anxious, lack of vocabulary and afraid of mispronouncing and nervous to confront the audience' [P3/Tania]
\end{abstract}

'Of course, it is about the misspelling, grammatical errors, and lack of vocabulary' [P4/ Akbar]

'Lack of vocabulary mastery and mispronounce, and also lack of practicing speaking English' [P6/Indra]

The data above indicates that the participants were challenged in speaking English due to a lack of vocabulary and grammar. Some of them stated that they could not speak English because they did not know how to spell the words and use the vocabulary appropriately. They said they required more time to think about the vocabulary and grammar, which made it hard for them to speak freely in front of others. This finding supports Pratolo's [20] study which identified that lack of vocabulary could cause a language learner to feel anxious. One of his student participants confessed that she would get stuck, and that if she forgot an English word while speaking in English with an English native speaker then she wouldn't be able to think of anything. Pratolo's research participant, who was also an EFL adult learner, believed that to be able to communicate well with people, she had to know every single word that she spoke and heard. Failure in this endeavor would inevitably lead to language anxiety.

Participants also reported that cognitive challenges such as being scared of negative responses from others and a lack of confidence would disturb their speaking performance. They cited fear of negative responses from others, including being disparaged by friends ( $\mathrm{P} 1)$ and being interrupted by the lecturer (P3), as crucial factors that make students feel anxious when speaking or presenting in front of the class [3]. Cognitive challenges were reported as the next factor that influences students' speaking performance and were split into four categories: speaking unsuccessfully in front of the audience; failure in delivering a message; worry about making mistakes; lack of confidence. Three of these - speaking unsuccessfully in front of the audience, failure in delivering a message, and worry about making mistakes in front of the audience - can be grouped as 'being frightened of negative responses from others'. The participants in this study reported fear of negative responses from others as making them feel anxious when speaking in front of others. Five of the participants reported that they had felt anxious or afraid when they tried to communicate or perform in front of the class, especially in front of their friends and the lecturer. Two students shared their perspectives about being frightened of negative responses from others, commenting:

'I think because my English is not good, they became more attentive to me, and sometimes I feel that my friends underestimated me, and I also worry that my lecturer will interrupt me when I am speaking. This will make me nervous' [P1/Lisa]

'Yeah, of course, especially when I talk or speak to a person who is smarter than me. And I love it more to speak English directly to native speakers because they appreciate us more than Indonesian people' [P1/Lisa]

'Sometimes I am afraid to speak in front of the class, I am afraid for making mistakes in my words or mispronounce some pronunciation, and it might be interrupted by the lecturer or friends' [P3/Tania]

$\therefore$... Because I am so nervous. And I am afraid that the audience (friends and lecturer) will not understand what I am presenting about' [P6/Indra]

Consequently, fearing negative responses from others was one of the things that made students worried or hesitant to speak English. Being disparaged was a crucial reason why they were nervous about speaking English. In addition, they sometimes thought that their friends were smarter than them. This kind of feeling makes participants afraid of being disparaged by 
their friends or the lecturer when they make mistakes in speaking in front of the class. It also showed that the students were scared to use their English because they were afraid of making mistakes and that they would be interrupted by the lecturer.

Lack of confidence due to the informal or formal situation can be another factor leading to cognitive challenges. Three students shared their perspectives:

'I am still afraid to speak to my friends and lecturers, feel doubt, and lack of confidence....'[P1/Lisa]

'For the informal situation such as speaking English with my friend for just making some jokes I do not feel anxious at all but for the formal situation such as for doing a presentation in front of lecturer I feel a little bit anxious, even sometimes I feel nervous' [P4/Akbar]

'So, I felt anxious when I want to speak English because I am not confident with my vocabulary use' [P6/Indra]

The data above showed that participants are willing to speak according to the situation. However, most of the participants are not confident about speaking in front of others, especially in formal situations and for academic purposes, such as presenting something. They even felt anxious about speaking in front of an audience. Some of the students also believed that language is for communication (P6). Failing to communicate can lead to a substantial decrease in motivation [13]. The findings revealed that even students at a higher level could be less motivated when they felt anxious. Several factors are predicted as sources of foreign language anxiety, such as age, academic accomplishment, a previous high school experience with foreign languages, and students' current language course [16]. It was found that older students had higher language anxiety than younger ones. Some changes become obvious when learners get anxious. As the result of cognitive challenges, students were afraid to speak, nervous, and they felt anxious. Language anxiety can affect students in many ways and have various effects, such as physical and psychological, cognitive, linguistic, and behavioral [3].

Another factor influencing English language anxiety within the EFL adult learners' speaking performance as reported by the participants in this study was 'lack of practice in speaking English', especially for practicing English speaking performance [16]. The findings revealed that some students have a reduced speaking performance not only because of linguistic difficulties and cognitive challenges but also because of the lack of practice in speaking English. Not having a partner to speak with or being in a particular learning environment may also lead to this problem [3]. Within this categorization, some students reported that they felt anxious to speak due to less practice in speaking English. Three students shared their perspectives:

'It was rare because at that time the class was so boring, make me feel bored, and the learning process was monotonous' [P1/Lisa]

'It was rare because I have limited partners to speak English' [P5/Fendi]

'Less practicing and lack of support from my friends' [P5/Fendi]

'It is rare. I think the teachers were boring and my friends, they are passive in English and only one or two students are active in class' [P6/Indra]

'Lack of vocabulary mastery and mispronounce, and also lack of practicing speaking English' [P6/Indra]

Based on the experiences shared by the participants above, a number of facts are revealed. It was found that the participants felt anxious due to lack of practice in speaking English because they don't have much experience in speaking English. They shared that they rarely speak English because they have no chance to speak it. They stated that the learning environment made it hard for them to practice English. They felt that the learning environment was boring and the teachers and students (and/or friends) were not especially active in speaking English. 
We have already mentioned that language anxiety could be affected by gender $[4,5,6,7,8]$. In fact, this concept is confusing. While there are many studies that still consider the effect of gender on language anxiety within speaking performance debatable, this present study has revealed one fact: based on the interview and the information gained from the participants, we conclude that there were no significant differences of language anxiety between male and female students. Both sexes have the same feeling of language anxiety toward speaking performance.

All of the students noted that they felt anxious when they speak publicly. They stated that there are many factors that impact their performance. To answer the second supplementary research question, many ways have been offered to deal with language anxiety. The participants also have their own ways to cope with it. Some of them mentioned that it's important to keep practicing and to make friends to learn English or just to have a partner for speaking with (P1, P3 and P6). According to Jones [21], language anxiety can be considered as part of a culture-based syndrome. It is the condition in which students feel humiliated or embarrassed when they are interacting with others. Making friends or being with friends who have the same culture or study background as them somehow helps students to deal with language anxiety. Some other participants mentioned doing some physical exercise (P1, P2 and P4), while one mentioned listening to English music and watching motivational videos to improve their motivation for learning English (P5). Physical exercise, in particular, is seen to help students refresh their minds and reduce anxiety.

\section{CONCLUSION AND SUGGESTIONS}

A number of reasons, effects, and ways to cope with language anxiety were examined from the students' perceptions obtained in the interviews. The study revealed that linguistic difficulties (vocabulary, grammar, and pronunciation), cognitive challenges (fear of negative responses from others and lack of confidence), and a lack of practice in English were considered as factors that could affect language anxiety, leading to a failure in speaking performance. The students did find some ways to deal with language anxiety, but this issue still needs more attention, especially in terms of the cognitive challenges of language anxiety. Thus, teachers should pay more attention to these students. They should be aware that students are sensitive to being judged by other students. They should arrange the learning environment in such a way that students can feel more comfortable and relaxed. The most important thing is that teachers give students more time for speaking exercises, for example, by drilling the students to practice speaking in every lesson. In short, they should be given more opportunities for speaking practice. For students to be successful in the future, they should also increase their confidence in speaking. They should practice public speaking because it will help them improve their speaking skills. Students can learn from native speakers or through videos on YouTube. Overall, students need to be more proactive.

\section{REFERENCES}

[1] Horwitz, E., Horwitz, M. \& Cope, J. (1986). Foreign language classroom anxiety. The Modern Language Journal, 70, 125-132.

[2] Xiao, Y. \& Wong, K.F. (2014). Exploring heritage language anxiety: A study of Chinese heritage language learners. The Modern Language Journal, 98(2), 589-611.

[3] Kayaoğlu, M.C. \& Sağlamel, H. (2013). Students' perceptions of language anxiety in speaking classes. Journal of History Culture and Art Research, 2(2), 142-160. doi:10.7596/taksad.v2i2.245.

[4] Tanveer, Muhammad. 2007. Investigation of the Factors that Cause Language Anxiety for ESL/ EFL Learners in Learning Speaking Skills and the influence it Casts on Communication in the Target Language. Glasgow: University of Glasgow.

[5] Naghadeh, S., Naghadeh, M., Kasraey, S., Maghdour, H., Kasraie, S. \& Naghadeh, N. (2014). The relationship between anxiety and Iranian EFL learners' narrative writing performance. International Journal of Psychology and Behavioral Research, 3(6), 602-609. 
[6] Chanprasert, C. \& Wichadee, S. (2015). Exploring language learning anxiety and anxiety reducing strategies of the first-year students taking a foreign language course. Journal of Social Sciences, Humanities, and Arts, 15(1), 131-156.

[7] Lian, L. \& Budin, M. (2014). Investigating the relationship between English language anxiety and the achievement of school-based oral English test among Malaysian form four language learners. International Journal of Learning, Teaching and Educational Research, 2(1), 67-79.

[8] Alsowat, H. (2016). Foreign language anxiety in higher education: A practical framework for reducing FLA. European Scientific Journal, 12(7), 193-220. doi:10.19044/esj.

[9] Bell, S.M. \& McCallum, R.S. (2012). Do foreign language learning, cognitive, and affective variables differ as a function of exceptionality status and gender? International Education, 42(1), $85-105$.

[10] Macintyre, P.D. (1998). Language anxiety: A review of the research for language teachers. In D.J. Young (Ed.), Affect in foreign language and second language learning (pp. 24-25). Boston, MA: McGraw-Hill.

[11] Aydin, S. (2008). An investigation on the language anxiety and fear of negative evaluation among Turkish EFL learners. Asian EFL Journal, 30(1) 421-444.

[12] Zhiping, D. \& Paramasivam, S. (2013). Anxiety of speaking English in class among international students in a Malaysian university. International Journal of Education and Research, 1(11), 1-16.

[13] Tüm, D.Ö. \& Kunt, N. (2013). Speaking anxiety among EFL student teachers. H.U. Journal of Education, 28(3), 385-399.

[14] Waseem, F. \& Jibeen, T. (2013). Anxiety amongst learners of English as a second language: An examination of motivational patterns in the Pakistani context. International Journal of Humanities and Social Science, 3(16), 174-184.

[15] Gopang, I.B., Bughio, F.A. \& Pathan, H. (2015). Investigating foreign language learning anxiety among students learning English in a public-sector university, Pakistan. The Malaysian Online Journal of Educational Science, 3(4), 27-37.

[16] Ahmed, N.F. (2016). An exploration of speaking anxiety with Kurdish university EFL learners. Journal of Education and Practice, 7(27), 99-106.

[17] Creswell, J.W. (2007). Qualitative inquiry \& research design. Thousand Oaks, CA: Sage Publications.

[18] Mukminin, A., Noprival, Masbirorotni, Sutarno, Arif, N. \& Maimunah. (2015). EFL speaking anxiety among senior high school students and policy recommendations. Journal of Education and Learning, 9(3), 217-225.

[19] Creswell, J.W. (1998). Qualitative inquiry and research design: Choosing among five traditions. Thousand Oaks, CA: Sage Publications.

[20] Pratolo, B. (2015). Exploring Indonesian learners' beliefs about language learning strategies through reflection (Doctoral thesis, Monash University, Australia). Retrieved from https://core.ac.uk/down load/pdf/82059045.pdf.

[21] Jones, J. (2001). A cultural context for language anxiety. EA Journal, 21(2), 30-39. 